\title{
Die Slag van Donkerhoek 11-12 Junie 1900 (2) Geveg op die noordelike flank 11 Junie
}

\section{Kdoor H.F. Nel*}

The battle of Donkerhoek (or Diamond Hill) will have taken place 85 years ago between 11-12 June of this year. The article below deals with this particular battle.

Die Slag van Donkerhoek het op Maandag 11 Junie om 05 h00 in alle erns begin toe die Britse troepe hulle eerste beweging op die noordelike flank gemaak het, by welke geleentheid French in digte duisternis sy kamp by Kameeldrift verlaat en na Kameelfonteinvallei opgeruk het. Die aanmars is deur 4 ruiterbrigades gelei. 'Sy voornemens was om die Boere se regterflank met ' $n$ wye beweging te omvleuel en langs die Elandsrivier af te beweeg ten einde die spoorlyn agter hulle rug naby Elandsrivierstasie af te sny. ${ }^{2}$

French het die 7th Dragoon Guards vooruit gestuur om die deurgang deur Kameelfonteindrif te verken, waarna hy met sy ruitery die drif met 'n bekwame spoed deurgesteek het. $^{3}$

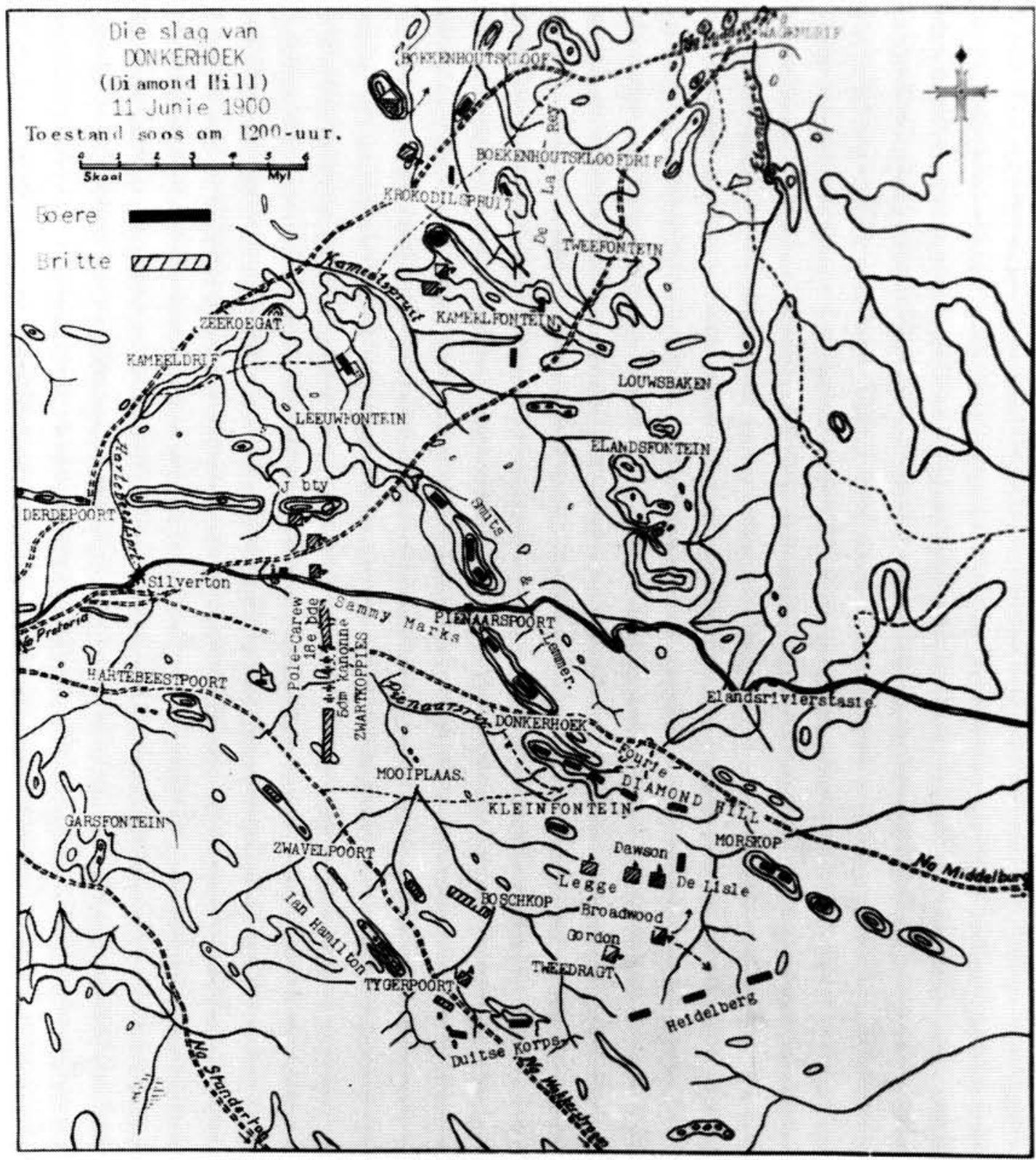

Die slag van Donkerhoek 11 Junie 1900 
De La Rey het opsetlik die bek van die vallei oopgelaat ten einde French toe te laat om met sy hele mag daar in te beweeg. Vanaf die omliggende hoogtes sou die Boere dan op sy troepe in die oop vlakte kon toesak, want die drif in sy rug sou ' $n$ vinnige terugtog onmoontlik maak en bes moontlik die Boere-afdelings suid van $\mathrm{Ka}$ meelfonteinrant die geleentheid gee om agter sy rug in te beweeg en sy terugroete af te sny. ${ }^{4}$

Vier brigade was kwalik twee kilometers verby die drif toe daar van Krokodilspruitkop op hulle losgebrand word. French, wat self voor was, het egter nie kop verloor nie en hulle beveel om van die perde af te spring en terug te vuur. Intussen het die res van die ruitery onder dekking van die westelike hang van Louwbaken en Kameelfonteinrant vorentoe gekom en by die voorste troepe aangesluit. ${ }^{5}$

French was nog besig om planne te beraam om die magte voor hom uit hul posisies te verdryf, toe hy 'n kommando van 200-300 Boere sowat 3000 meter voor hom dwarsoor sy front in 'n noordwestelike rigting sien jaag. Dit was die Marico-kommando van genl J.P. Snyman wat sy posisies sonder meer in die aangesig van die vyand verlaat en na Boekenhoutskloofrant teruggeval het. French het dit gesien as 'n poging om sy linkerflank te omvleuel en aan maj Sir John Jervis-White-Jervis opdrag gegee om onmiddellik met O-battery RHA teen Snyman se galopperende troepe te ontplooi. Jervis se bombardement het snel sy uitwerking getoon en Snyman se burgers gedwing om noordwaarts te swenk. ${ }^{6}$

Intussen het groepies burgers uit die noorde van die vallei vorentoe gedring en hewige geweervuur op Jervis se battery geopen. French het genl maj Dickson daarop beveel om 4 Kavalleriebrigade te voet teen Krokodilspruitkop te ontplooi. Tegelykertyd moes hy 'n eskadron regs teen Kameelfonteinrant inwerp tot tyd en wyl van die berede infanteriekompanies, wat nog besig was om die rivier oor te steek, sou bykom om hom te versterk. ${ }^{7}$

Inmiddels het De La Rey, wat gesien het wat met Snyman gebeur, hom na die ontruimde posisies gehaas. Deur van Dalwig se kanonne ondersteun het die burgers vanaf die noordelike deel van Kameelfonteinrant al skietend vorentoe gedring en Dickson se brigade, wat nouliks 100 man in die vuurlinie gehad het, op die verdediging gedwing. 'n Swaar kanon het ook vanuit 'n goed versteekte posisie in die koppe suid van Byenespoort die Britse troepe op die uitlopers aan die noordelike en westelike hange van $\mathrm{Ka}$ meelfonteinrant onder kruisvuur geneem. Die troepe van 4 Brigade het hulle dapper verweer. Onder die hewige kruisvuur het hulle ontplooi en die hange en kruin van Louwbaken beset. Hulle is later versterk deur twee kompanies van kapt C.G. Amphlett se 1ste Berede Infanteriebataljon, wat op die laer hange van Louwbaken stelling ingeneem het, gevolglik het die berede infanterie nou die hele kop beset. ${ }^{8}$

Aangemoedig deur die sukses waarmee hulle French se aanmars gestuit het, het groepies van De La Rey se burgers gevolglik probeer om die troepe op Louwbaken aan die oostekant te omvleuel, terwyl die Boerekanonne steeds hewige vuur neergebring het. French het die gevaar hiervan besef en aan sy geskut opdrag gegee om die Boerekanonne te neutraliseer. Hy het ook troepe geskuif om die Boere se flank te bedreig. Ten gevolge hiervan kon De La Rey se klompies burgers nie verder vorentoe beweeg nie en moes hulle hul pogings om Louwbaken te omvleuel laat vaar. Daardeur is French se regterflank beveilig en het die geveg aan die kant van die vallei vir die res van die dag in 'n skaakmatsituasie ontwikkel waarin nie een van die twee magte terrein gewen of verloor het nie. ${ }^{9}$

Kol Porter se brigade het Kameelfonteinvallei intussen met ' $n$ wye boog na die weste oorgesteek ten einde die Boere aan die verste kant van die Boekenhoutskloofrante te omvleuel. Porter se troepe het vir twee uur lank geveg totdat hulle omstreeks $13 \mathrm{~h} 00$ die rant tot by Doornfontein verower het. Verder as dit kon hulle nie vorder nie, want die burgers was vasberade om hulle te stuit en French se artillerie-ammunisie was feitlik gedaan, gevolglik is die Britse aanval in Kameelfonteinvallei hier finaal tot stilstand gedwing. Deur sy optrede het Porter nietemin daarin geslaag om aan die Boere ' $n$ groot deel van die takties belangrike Boekenhoutskloofhoogtes te ontsê en daardeur French se linkerflank te beveilig teen ' $n$ dreigende omvleueling. ${ }^{10}$

French se posisie was nou benard. Sy aanval was gestuit en sy mag, insluitende sy reserwes, oral op die verdediging gedwing. Daarenteen was die Boere se strydlus nou aangewakker en het hulle oral die inisiatief geneem. Die geveg sou die hele middag voorduur. Die pad waarlangs French die oggend vanaf Kameeldriffontein verby Louwbaken beweeg het, is deur die Boere in ' $n$ gewisse doodsakker omskep en van Byenespoort se kant af het die kanonniers die drif in sy rug gebombardeor om sy terugtogroete 
af te sny. French het derhalwe boodskappers na Roberts gestuur om hom mee te deel dat hy waarskynlik nie daarin sou slaag om sy opdrag die omvleueling van die Boereflank - uit te voer nie, tensy hy versterk word. Hierop het Roberts geantwoord dat French moes terugtrek indien die vyand te sterk was en dat hy veral nie die risiko moes loop om te veel verliese te ly nie. ${ }^{11}$

Die nag het aangebreek en vir French het die duisternis welkome verligting gebring. In plaas daarvan dat hy die Boerelinie omvleuel het, is hyself met omsingeling bedreig. Sy mag het die perke van sy vermoëns bereik en kon homself alleenlik met die uiterste inspanning handhaaf en die terugtoglinie oophou. Ten spyte van sy benarde posisie het hy egter besluit om in sy posisies vas te skop ten einde die volgende dag 'n groot deel van Botha se magte voor hom vas te pen. ${ }^{12}$

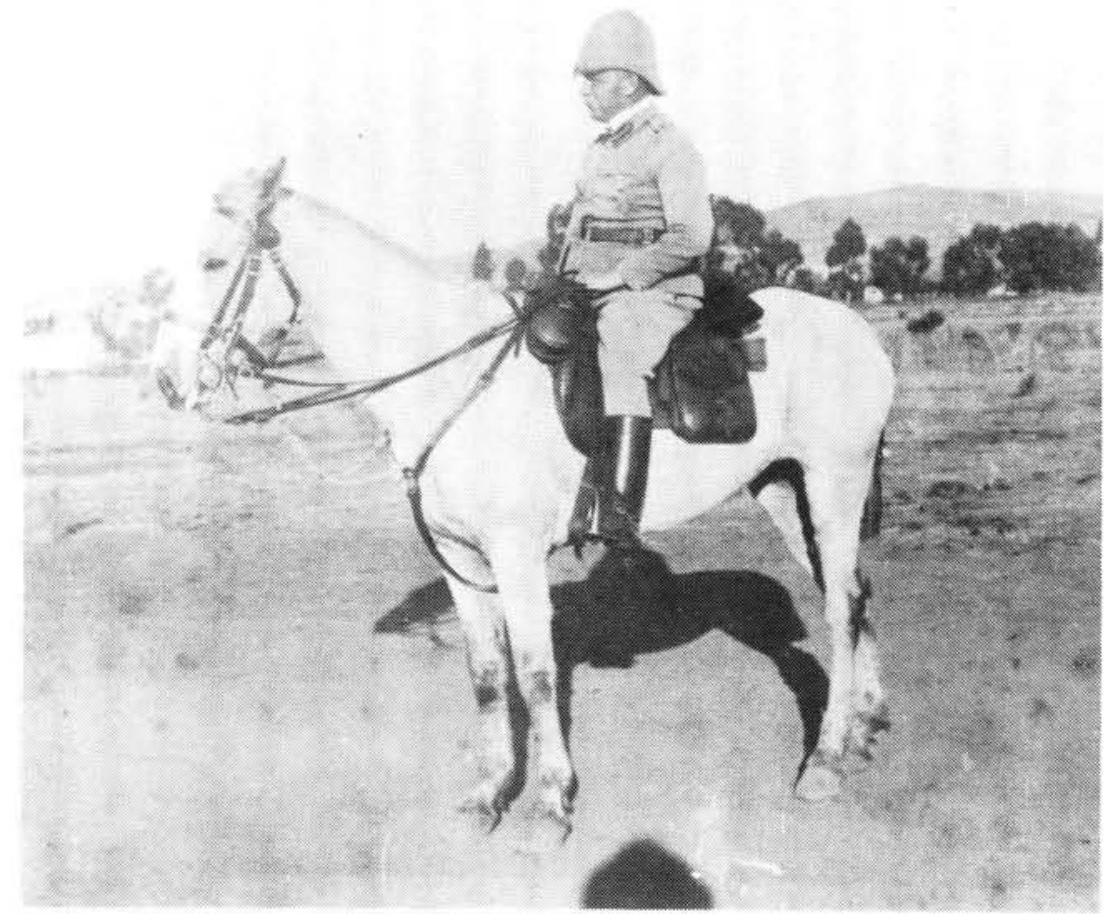

Gen maj J.D.P. French te Pretoria

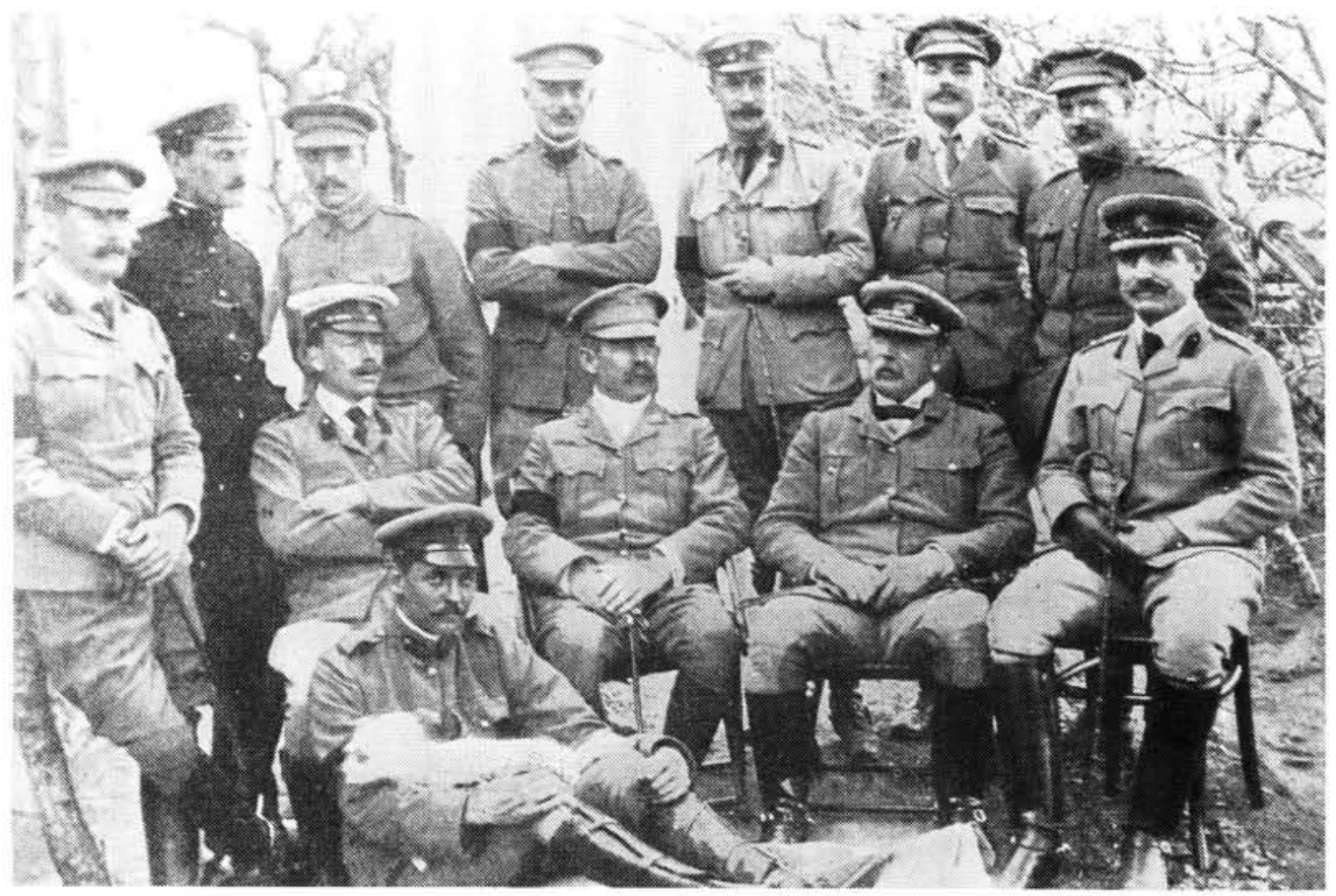

Gen maj J.D.P. French en sy personeel 
De La Rey, daarenteen, kon onder die omstandighede tevrede voel met die verloop van die dag se geveg. Vir die eerste maal sedert Roberts van Bloemfontein af opgeruk het, het die Boere daarin geslaag om die vyand se aanval af te slaan en hulle eie posisies te behou.

\section{Die aanval op die suidelike flank 11 Junie}

Gelyktydig met French se opmars na Kameelfonteinvallei het lan Hamilton se mag op die suidelike flank in beweging gekom. Reeds om $04 \mathrm{~h} 00$ is die onberede ruitery uitgestuur om die koppe aan weerskante van Swawelpoort, waar Hamilton se mag moes deurgaan, te beset. 'n Halfuur later het ook die berede brigades begin opruk. Broadwood se opdrag was om suid om die Boerestellings by Donkerhoek te beweeg, terwyl brig genl Gordon die Boerekommando, wat ' $n$ posisie oos van Tierpoort beset het, moes teëhou om Broadwood se regterflank te beveilig. ${ }^{13}$

Broadwood het suidooswaarts opgeruk om die Boerelinie te omvleuel. Sy linkerflank is deur brig genl Ridley se berede infanterie beskerm en sy regterflank deur Gordon, wat op Tierpoort aangeruk het. ${ }^{14}$

Broadwood se aanmars in die rigting van Tweedracht het hom reg in die Boere, wat hom van twee kante af bedreig het, se skootveld ingelei. Vanaf hul hoofposisie in die Diamond Hillrante het die Boerekanonniers sy bewegings waargeneem en sy eskadrons reeds op die westelike oewer van die Pienaarsrivier met 'n hewige kartetsvuur begroet. Terselfdertyd het groepies van die Heidelberg-kommando, wat voor Gordon uitgewyk het, in die gaping tussen die twee brigades inbeweeg en 2 brigade nou van regsagter aangeval. Broadwood was egter nie iemand wat hom maklik laat stuit het nie. Aan 'n gedeelte van sy brigade het hy opdrag gegee om die Boere en toom te hou en met die res vorentoe gebeur en die Pienaarsrivier oorgesteek. ${ }^{15}$

Louis Botha was ewe vasberade om die oprukkende ruitery tot stilstand te dwing. Van Diamond Hill af het hy afdelings burgers gestuur om dwarsoor Boardwood se aanmarsroete posisie in te neem en sy kolonne in die front te stuit. Teen ongeveer 11 h00 was Broadwood verplig om sy brigade tot stilstand te roep en het hy It Connoly met 2 kanonne gestuur om die vyand uit die pad te vee voor hulle kans kon kry om hulself stewig in posisie te vestig. ${ }^{16}$

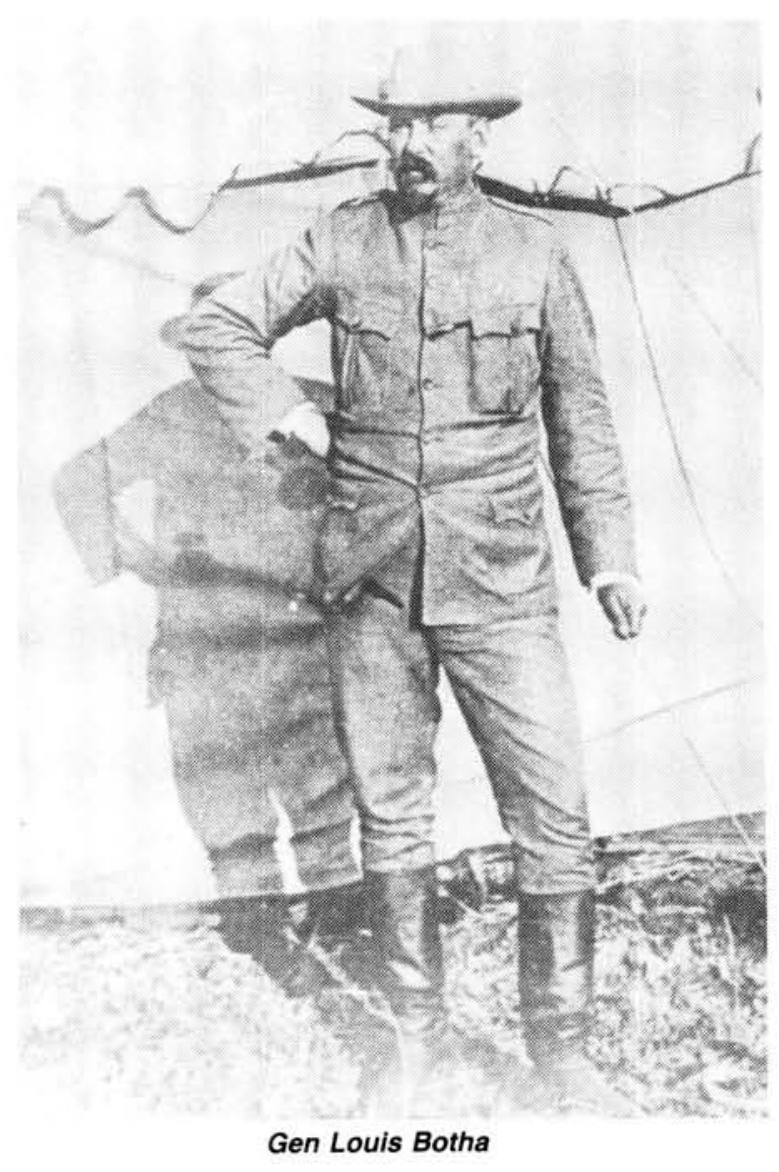

Die Boere, wat die gaping tussen die vooruitgeskowe afdeling en die res van die brigade onmiddellik raakgesien het, het nie op hulle laat wag nie. Tweehonderd burgers van die Bethalkommando het die voorste Britse verkenners teruggedryf, tot op 300 meter van die kanonne ingestorm en verwoestende vuur op húlle en die geleide geopen. Terselfdertyd het 'n sterk afdeling burgers van die Heidelberg-kommando, wat hulself uit die geveg met Gordon se brigade losgewikkel het, flankvuur op die kanonne laat reën. ${ }^{17}$

Die bevelvoerder van die 12th Lancers, It kol, die graaf van Airlie, was ' $n$ dapper man wat met sowat 70 beskikbare man die Boere met luide geskreeu bestorm het. Die meeste van die burgers, wie se magasyne reeds leeggeskiet was, het op hulle perde gespring en voor die lansiers uiteengespat. Die lansiers se perde was egter só uitgeput dat hulle nie die vlugtende burgers kon inhaal nie. Met die terugkeer het Airlie ongelukkig sy regiment meer na links in die rigting van die vyandelike hoofposisie gelei. ' $n$ Verwoestende vuur is gevolglik deur die Boere op hulle neergebring en Airlie is neergevel. Die kanonne was gered, maar die prys was hoog, want terwyl die gebeure op Broadwood se front afge- 
speel het, het ook op sy regterflank 'n hewige geveg gewoed. Die Boere se aanvalle is deurlopend deur artilleriste op Diamond Hill ondersteun. Broadwood het die troepe van die Household Cavalry nou beveel om 'n berede stormloop met die swaard uit te voer, aangesien dit nodeloos sou wees om in daardie stadium 'n vuurgeveg aan te knoop. Die ruitery het met groot krygsgeskreeu en ontblote swaard op volle gallop op die Boere afgestorm, wat in alle rigtings uiteengespat het. Die verliese aan albei kante tydens hierdie aanval was gering. Die burgers se aanvalle het dit vir Broadwood onmoontlik gemaak om sy opmars te hervat, aangesien die gevaar steeds bestaan het dat hulle in die gaping agter sy rug, wat al groter geword het, kon inbeweeg en hom afsny.

Intussen het Gordon ooswaarts agter Broadwood aangeruk om sy oorspronklike taak, die beveiliging van Broadwood se regterflank, te hervat. Hy het weliswaar daarin geslaag om die Boere van die hoogtes, wat die vallei aan die suidekant beheers, te verdryf. ${ }^{20}$

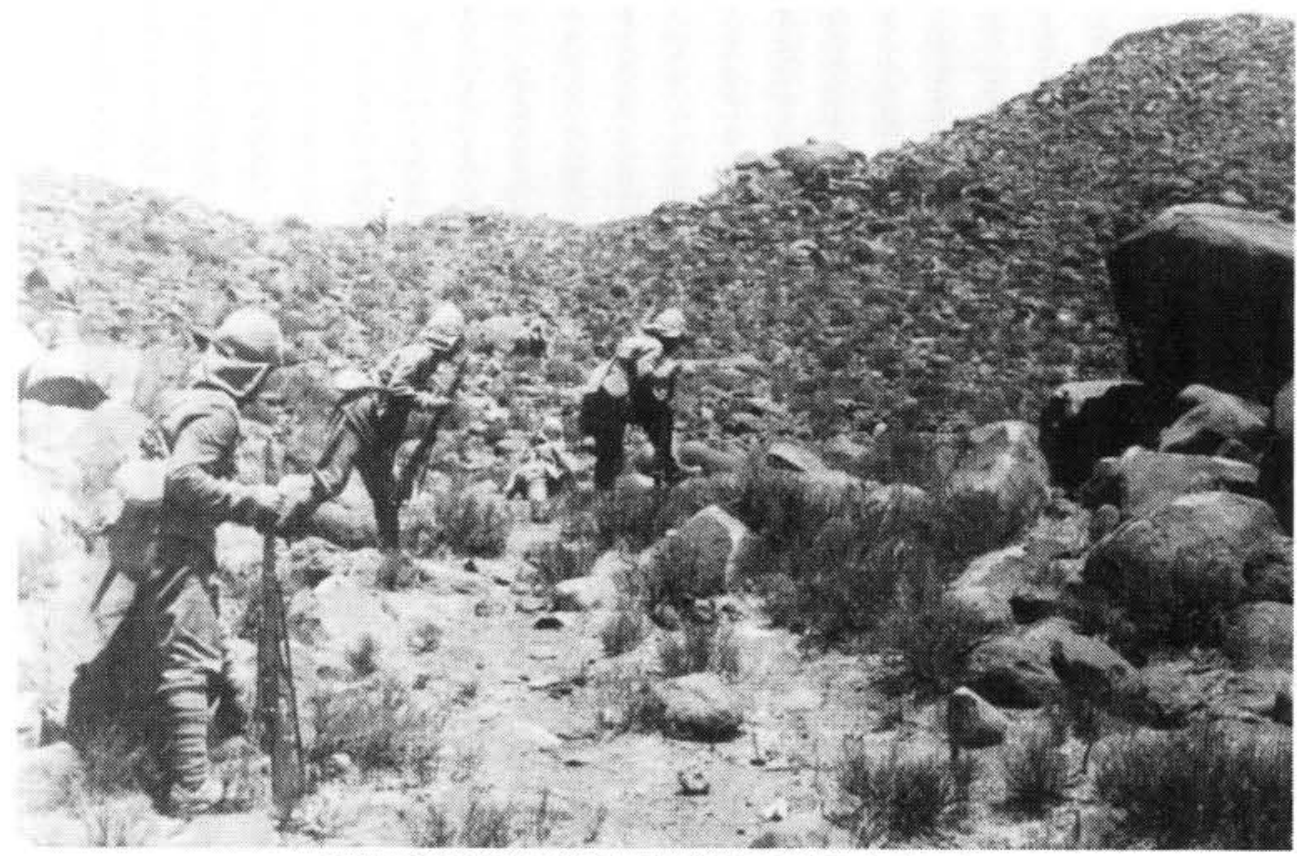

Britse Infanterie tydens die Slag van Donkerhoek

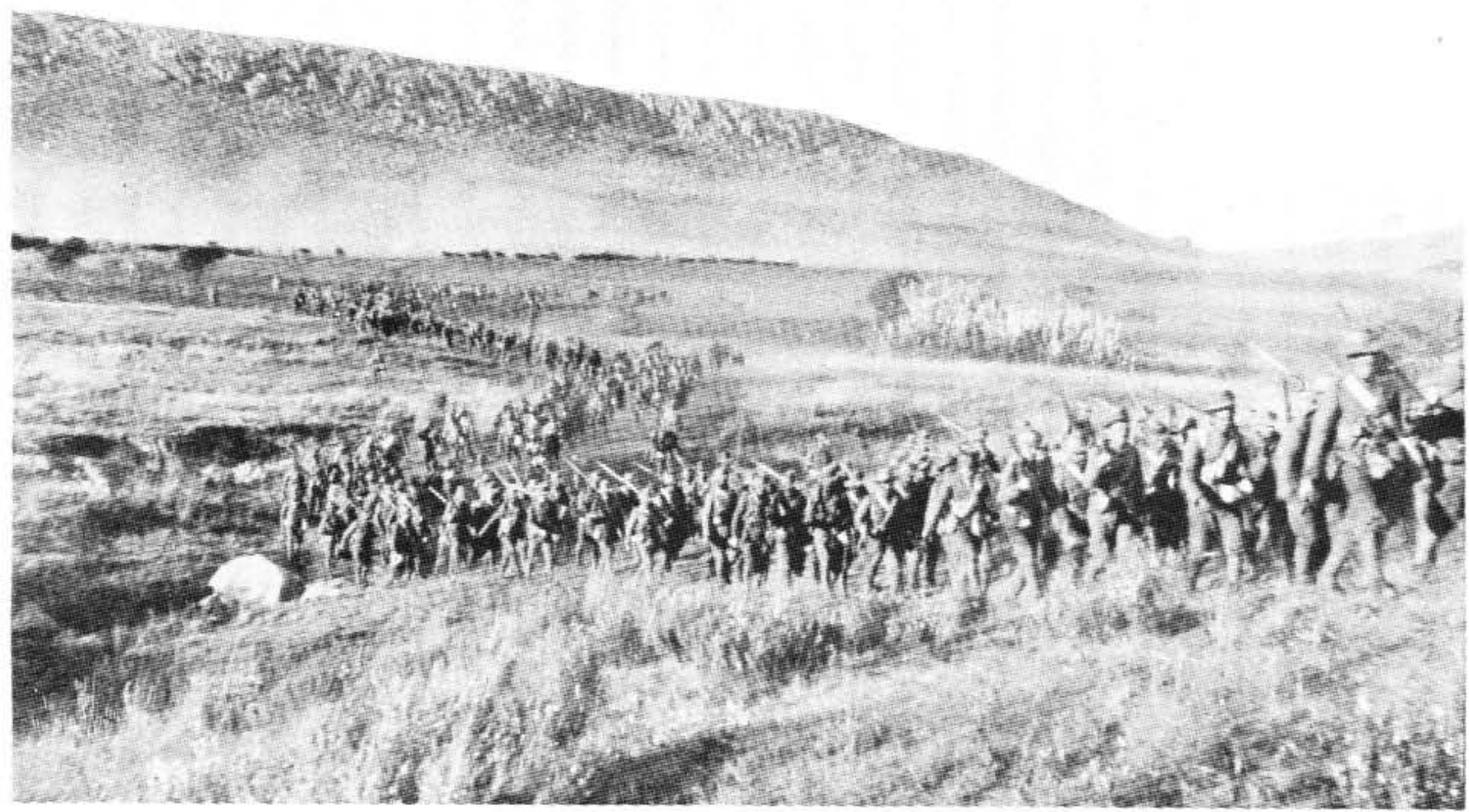




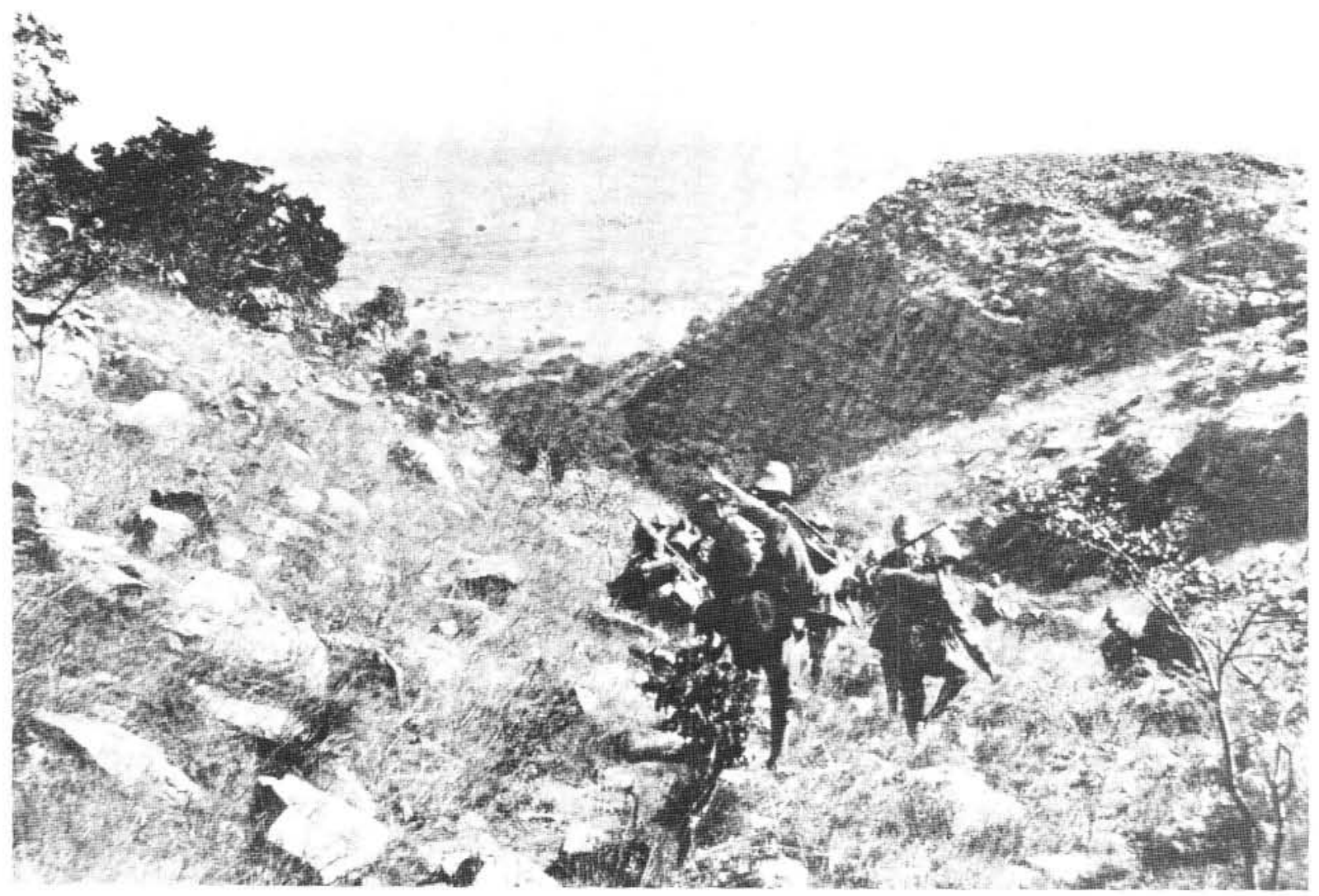

Britse Infanterie tydens die slag van Donkerhoek

Hierna het die geveg op dié deel van die slagveld in 'n skaakmatposisie ontwikkel, waarin nog Ian Hamilton se ruitery, nog Joachim Fourie se burgers, ten spyte van 'n lewendige vuurgeveg. grond gewen of hul posisies prysgegee het. Op albei flanke het Roberts se beplande omvleuelings dus misluk en is sy ruitery deur Botha se kommando's vasgepen en hy, op sy beurt, met omvleueling bedreig. Hy sou sy mag moes terugtrek of die Boerelinie in die front met infanterie probeer deurdring. Vir ' $n$ frontaanval, het hy weens die verwagte hoë verliese, teruggedeins. Hy het gevolglik aan Ian Hamilton laat weet om nie met die aanval te volhard nie. ${ }^{21}$

Noord na noordoos van Diamond Hill daal die terrein geleidelik na die treinspoor af en vorm uiteindelik 'n golwende vlakte met losstaande hoogtepunt, wat ongeskik is vir 'n verdedigingslinie. Hierdie vlakte word deur die Donkerhoek Diamond Hill-reeks gedomineer. 'n Deurbraak by Diamond Hill sou dus die Britse mag in staat stel om agter die rug van die Boeremag te kom, die spoorlyn af te sny en hulle ' $n$ vernietigende neederlaag toe te dien. ${ }^{22}$

Toe dit vir Ian Hamilton duidelik word dat Broadwood se omvleuelingsbewegings besig was om te misluk en dat hy op die verdediging gedwing word, het hy besluit om Broadwood te hulp te gaan en met sy infanterie ' $n$ aanval teen die laer hange van die Diamond Hill-posisie te loods, om te voorkom dat die vyand sy hele mag op die flank teen die ruitery konsentreer. Hy het dus vir Bruce Hamilton beveel om tot die aanval oor te gaan. ${ }^{23}$

Bruce Hamilton se plan was om die regterflank van die posisie voor hom met die Royal Sussex te verower en dit dan na die ooste op te rol, terwyl die City Imperial Volunteers, ondersteun deur 82 Veldbattery en Legger se berede infanterie, die Boere se sentrum en linkerflank sou vaspen. ${ }^{24}$

Hamilton het sy troepe in wydverspreide orde in die veld gestoot, terwyl 'n hewige kanon- en geweervuur uit alle dele van die Boerestellings op hulle neergereën het. Weens die verspreidheid van sy troepe en goeie benutting van natuurlike dekking kon die Boere hulle nie met hul vuur stuit nie. Met die vyand uiteindelik stewig in posisie op hul regterflank, het dit vir die Boere op die Kleinfonteinrant bykans onmoontlik geword om hul posisies te behou. Met hul regswending het die Royal Sussex front na die ooste 


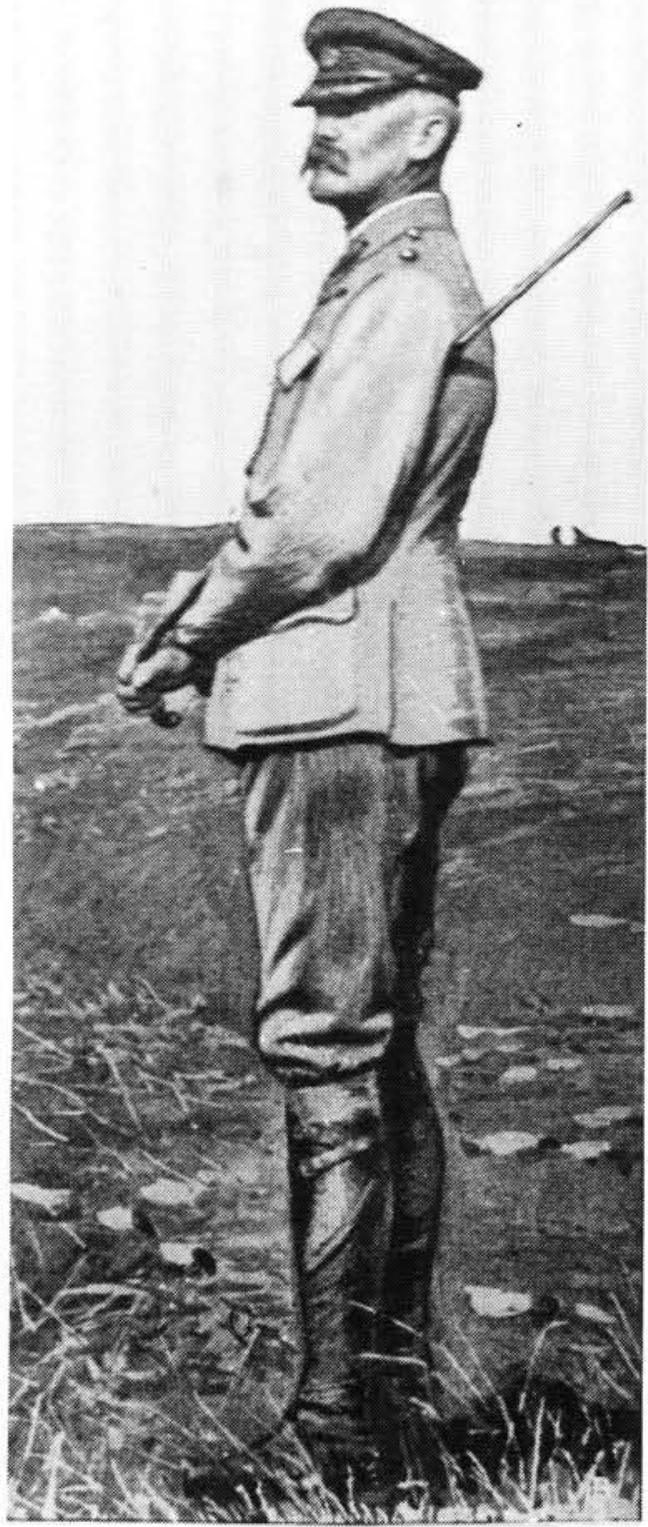

Gen maj Sir Bruce Hamilton

gemaak en die Boerestellings geleidelik van regs af begin oprol. ${ }^{25}$

Teen $15 \mathrm{~h} 30$ het die verdediging op die Kleinfonteinrant begin meegee toe groepies burgers, van sowat 20 of 30 man sterk, hul posisies verlaat en op die hoofstellings van Magaliesberg teruggeval het, en 'n halfuur later het Tobias Smuts die rant prysgegee en met die res van die kommando in hul spore gevolg. Bruce Hamilton se regimente het nou die hele Kleinfonteinstelling in besit geneem. ${ }^{26}$

Vanaf sy posisie op die hoë terrein sowat tien $\mathrm{km}$ wes van Pienaarspoort, het lord Roberts Bruce Hamilton se aanval gade geslaan en tot die gevolgtrekking gekom dat Diamond Hill die sleutel tot Botha se linie op die suidelike flank was. Die verloop van die aanval het hom oortuig gelaat dat sy troepe vanaf die verowerde posisies 'n suksesvolle aanslag op Diamond Hill self sou kon maak en hy het besluit om die volgende dag op dié punt met die aanval deur te druk. ${ }^{27}$

\section{Gebeure in die sentrum - 11 Junie}

In die sentrum het It genl Pole-Carew teen dagbreek met sy twee infanteriebrigades van hulle kamp af na die plaas Christinen Hall gemarsjeer, vanwaar hy hulle oor 'n reeks klein koppies in die gebied, wat suidwaarts na Mooiplaats uitstrek, ontplooi het. Die berede infanterie het hy aangewend om sy front en flanke te dek. Sy opdrag was om nie aan te val nie, maar sy mag gereed te hou in afwagting op die verloop van die ruitery se omvleuelingsbeweging. ${ }^{28}$

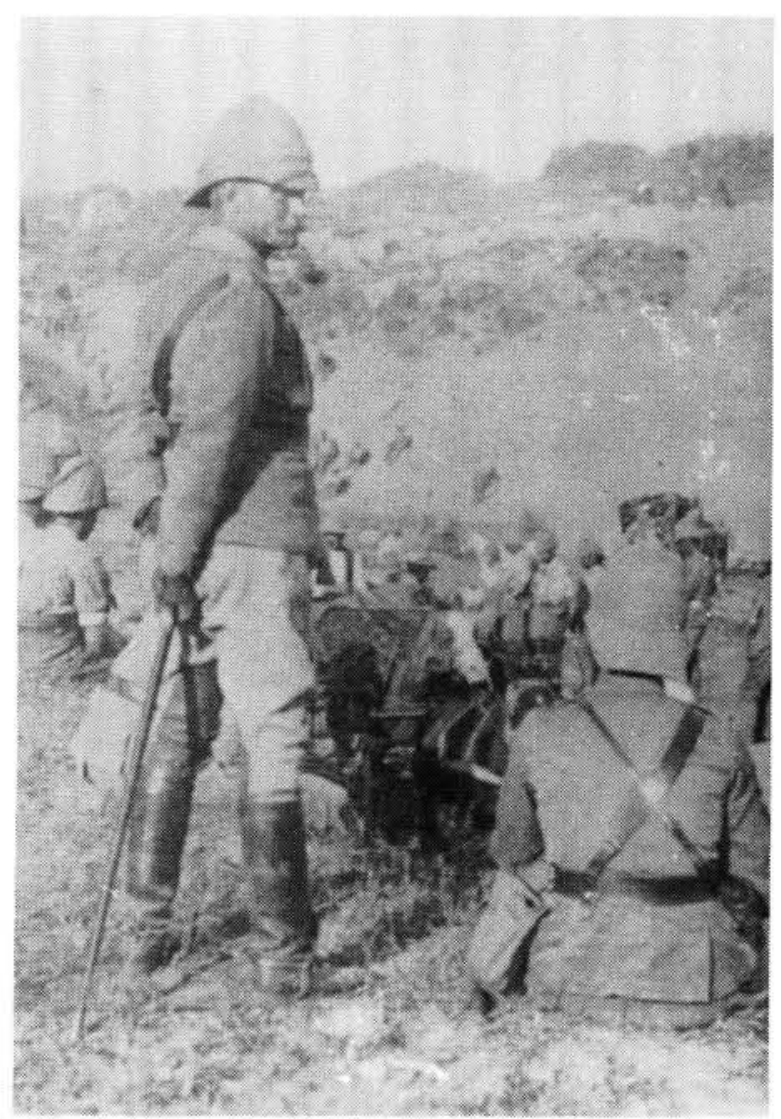

Gen Pole-Carew Bevelvoerder van 11 Divisie

\section{Foto 6}

Op Pole-Carew se linkerflank het kol Henry in die loop van die dag ' $n$ aanval op Franspoort gemaak om ' $n$ bres in die Boerelinie te probeer slaan. Kragtig ondersteun deur die Staatsartillerie het genls Grobler en Douthwaite Henry se troepe met mening teruggewerp. Hierop het 
Pole-Carew hom beveel om die grond te hou wat hy op daardie tydstip beset het en met French se basis by Kameeldrif in verbinding te bly. ${ }^{29}$

Gedurende die dag het Pole-Carew se infanterie geleidelik vorentoe beweeg ten einde die burgers in die sentrum vasgepen te hou sodat hulle nie onttrek en teen lan Hamilton ingewerp word nie. Dat Pole-Carew met die taktiek in sy doel geslaag het, word bevestig deur ' $n$ mededeling van Smuts dat die Boerelinie in die sentrum so sterk bedreig is dat dit vir ' $n$ lang ruk moeilik was om te bepaal of die Britse hoofaanval daar ge- maak sou word en of dit bloot 'n skynaanval was om te verhoed dat Louis Botha versterkings van daar af na die suidelike flank stuur. ${ }^{30}$

\section{Voortsetting van die geveg 12 Junie}

Albei kante het daardie nag voorbereidings vir die volgende dag se geveg getref. Die oggend van 12 Junie, reeds om 03h00, het Roberts sy finale bevel aan Pole-Carew getelegrafeer. Daarvolgens moes Pole-Carew die aanval van Ian Hamilton dieselfde oggend ondersteun. Sy sentrum moes hy hou, bygestaan deur die $5 \mathrm{dm}$ kanonne, en sy regterflank verder uitstoot. ${ }^{31}$

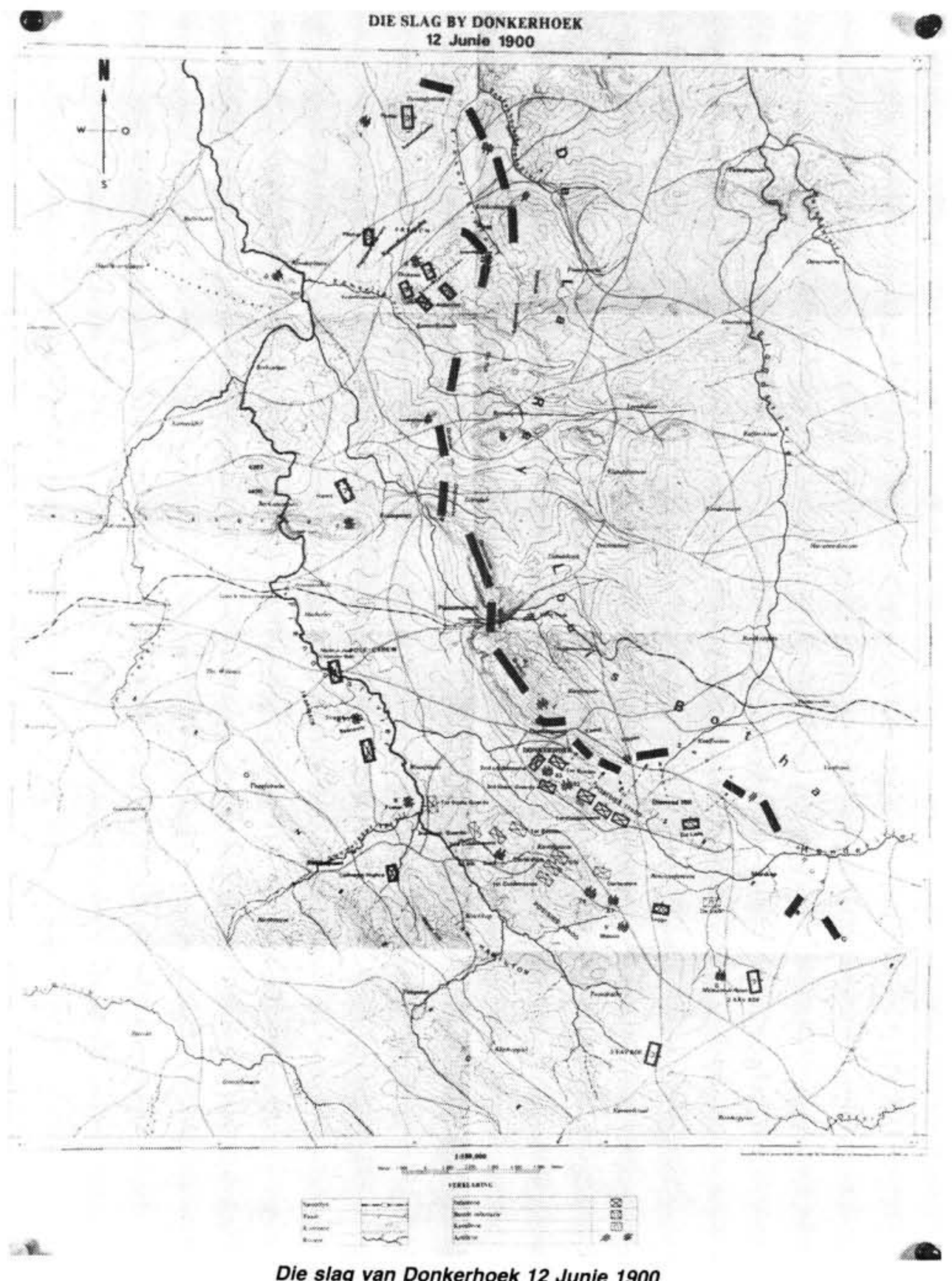


By die Boerelinie het Louis Botha vroegoggend genl De La Rey se rapport oor die situasie op noordelike flank, tesame met ' $n$ brief van genl Grobler, ontvang. Botha het geantwoord dat alle moontlike versterkings na die suidelike vleuel moet gaan waar hy die swaarste geveg verwag het. Hy het Grobler gemaan om die vorige dag se sukses teen Henry op te volg, die vyand ten ooste van Baviaanspoort te verdryf en, indien moontlik, Pole-Carew se kamp by Silverton te bedreig en te verower. ${ }^{32}$

Vroeg die oggend was lord Roberts terug op die gevegsterrein en het die bewegings, wat hy die vorige aand gereël het, onmiddellik ' $n$ aanvang geneem. Bruce Hamilton het om 06 h00 sy drie infanteriebataljons en twee veldbatterye na die posisies, wat hy die vorige middag verower het, gelei en hulle daar ontplooi. Om 08h00 het lan Hamilton sy infanteriebevelvoerder beveel om Diamond Hill te verower en agter die Boere se rug op die spoorlyn toe te slaan ten einde hulle terugtog af te sny. Hy moes egter op twee bataljons Guards wag, wat onder sy bevel geplaas sou word en wie se aankoms voor die middag verwag is. Voor hom het ' $n$ sterk Boeremag op die kruin van Diamond Hill in posisie gelê, terwyl hulle flanke na weerskante so ver uitgestrek het as wat hy kon waarneem. Broadwood en Gordon se ruiterybrigades is beveel om vanuit die posisies wat hulle die vorige dag gehou het, die infanterieaanval teen inmenging van regs en regs-agter te beskerm. ${ }^{33}$

Onmiddellik nadat die veldartillerie ontplooi is, het 76 Battery die hoofstelings op Diamond Hill begin bombardeer. Om $12 \mathrm{~h} 45$ het Bruce Hamilton sy brigade beveel om tot die aanval oor te gaan. Van die posisies waar Bruce Hamilton se troepe ontplooi was, is gesien dat Diamond Hill die naaste en mees prominente kop in die reeks was, wat van Donkerhoek af suidooswaarts na Morskop uitstrek. ${ }^{34}$

Louis Botha wat die hele dag lank die siel van die Boereverdediging was, het uiteindelik burgers uit die middel onttrek en na die linkerflank gestuur om dit teen die geweldige oormag te versterk. In die aangesig van Pole-Carew se mag, wat sy sentrum bedreig het, het Botha besef dat hy die verdediging van sy linie daar gevaarlik uitdun, maar hy het geen ander keuse gehad nie omdat daar nie genoeg burgers aan sy front was om die linie oral behoorlik te verdedig nie. ${ }^{35}$

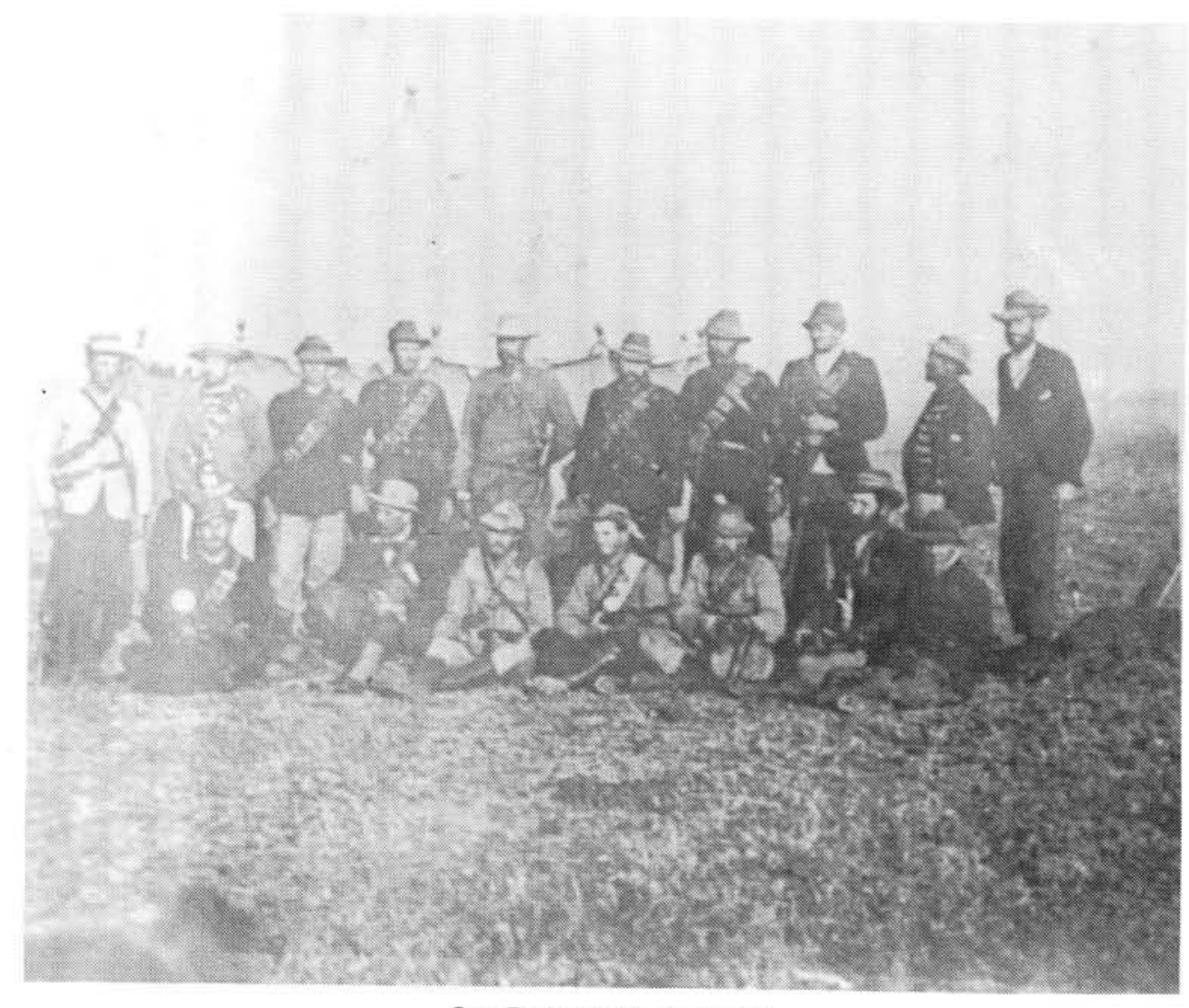

Gen Botha by Donkerhoek 
Die geweldige bombardement van die Engelse en die oprukkende bataljons het Tobias Smuts se Ermeloërs, aan wie die verdediging van Diamond Hill toevertrou is, so ontsenu dat hulle, nog voordat die vyandelike troepe behoorlik binne gevegsafstand was, hulle stellings prysgegee en teruggeval het na Renosterkop. Teen $13 \mathrm{~h} 30$ was die City Imperial Volunteers op die suidelike rant van Diamond Hill se kruin, dog toe het die geveg eers in alle erns begin. Toe die Britse troepe die kruin betree, het Louis Botha se burgers met alles wat kon skiet - Mausers, Pompoms en kanonne - die plato met so 'n verwoestende kruisvuur uit die front en flanke bestryk dat hulle nie kon vorentoe beur nie en agter die klippe moes skuiling soek on aan vernietiging te ontkom. Bruce Hamilton het nou besef dat hy gevaar geloop het om weer van die kruin afgeskiet te word en besluit om sy front te verbreed. Terselfdertyd het hy die Royal Sussex en die 2nd Coldstreams beveel om die Donkerhoekplato te beset. $^{36}$

Teen $15 \mathrm{~h} 00$ het die Royal Sussex die Donkerhoekrant beset en 'n kwartier later het die 2nd Coldstreams op die linkerflank by hulle aangesluit. 'n Paar minute daarna - dus ongeveer $15 \mathrm{~h} 30$ - het maj W.H. Connolly die kanonne van 82 Veldbattery op die kruin getrek. Hy het sy battery $700 \mathrm{~m}$ agter die vuurlinie ontplooi en ' $n$ hewige vuur op die Boere geopen, wat hy tot dit donker geword, onderhou het. Hoewel sy bombardement nie die Boerevuur totaal geneutraliseer het nie, het dit dit aansienlik laat afneem.

Ian Hamilton het, op sy beurt, aan brig genl Ridley opdrag gegee om sy front na regs te verleng om met die volle berede infanterie druk op die Boere se linkerflank uit te oefen. Die plaas Renosterfontein is beset en daarvandaan het die 6 bataljons noordwaarts teen die rant, wat deur die Ermelo-kommando gehou is, opgeruk. Die Ermeloërs het dapper geveg, maar hulle het sulke swaar verlies gely dat hulle gedwing is om terug te val. Intussen het Botha kmdt Ben Viljoen met sy kommando na die bedreigde punt gestuur, terwyl hyself met ' $n$ deel van die Krugersdorp-kommando daarheen gehaas het. Toe hulle daar kom, was die Britse troepe reeds in besit van die kruin en, sonder dat hulle dit besef het, agter die rug van die Boerelinie. ${ }^{38}$

Ian Hamilton het self na die kruin van die Diamond Hill-plato gegaan en die posisie saam met Bruce Hamilton in oënskou geneem. Om hulle posisie op die plato te verseker, moes die Boere van die rant voor hulle verdryf word. Die vallei tussen hulle het dit vir Bruce Hamilton onmoontlik gemaak om hulle met sy linkerflank in die front aan te durf, dus het hy beplan om met sy regterflank deur die Boerelinie te breek en sodoende agter hulle rug te kom. Met die oog daarop het hy bevele uitgereik om sy vuurlinie te versterk. ${ }^{39}$

Genl maj Inigo Jones, wat besef het in watter dilemma die troepe op die kruin verkeer, het maj $\mathrm{H}$. Guthrie-Smith met 83 Battery intussen vorentoe gestuur om hulle te ondersteun. Hy het maj Connolly bygestaan en die gesamentlike bombardement van die twee batterye het die helfte van die Mauservuur die swye opgelê. ${ }^{40}$

Louis Botha het probeer om die dalende plato noord-noordoos van Diamond Hill, vanwaar die rug van sy linie bedreig kon word, te versterk en groter diepte daaraan te gee deur ' $n$ stelsel van loopgrawe en skanse op die lae grond. ${ }^{41}$

Die ruiterybrigade van Broadwood en Gordon, wat oorspronklik die Boerelinie moes omvleuel, is die hele dag só deur die Boere se vuur vasgepen dat hulle nie teen die Boereflank kon optree nie, en in ' $n$ statiese verdedigingstelling, gedwing is tot die rol van voetsoldate, wat moes veg om te hou wat hulle gehad het. ${ }^{42}$

Om $17 \mathrm{~h} 30$ het $83-B a t t e r y$ vuur gestaak as gevolg van die swak lig in die skemer. Namate dit donkerder geword het, is hulle voorbeeld deur die ander strydendes gevolg.

\section{Geveg op die noordelike flank}

Terwyl die twee genls Hamilton op die suidelike flank die oggend besig was om hulle vir die slag van Donkerhoek voor te berei het French se voorposte op die noordelike flank met die aanbreek van eerste lig gerapporteer dat De La Rey se burgers besig was met energieke voorbereidings om die Britse troepe uit hul posisies te verdryf. French het hierop besluit om eerste toe te slaan en die skaakmatposisie van die vorige aand te beëindig. Hy het 1 st Berede Infanteriebataljon en die 2nd Canadian Mounted Rifles na Krokodilspruit laat opruk om dit te verower. De La Rey se burgers was egter daarop voorberei en het die Britse troepe met verwoestende kanon- en Mauservuur, wat hulle in hul spore gestuit het, begroet. $\mathrm{Na}$ ' $\mathrm{n}$ derde onsuksesvolle poging het French besef dat dit onmoontlik was om die Boerestellings met ' $n$ direkte aanval te verower. ${ }^{44}$

Met hulle Mausers en kanonne het die burgers 
French se troepe só onder vuur gehou dat die Britse troepe nie tot enige voorwaartse beweging in staat was nie, maar met groot inspanning die stellings moes hou wat hulle beset het. French se posisie het al hoe meer benard geword. Die Boere se kanonne het vanaf Kroko- dilspruitkop en die Byenespoort-Edenvale posisies die Engelse op Louwbaken en Kameelfonteinrant onder hewige kruisvuur geplaas. Die Britse geskut het ' $n$ tekort aan ammunisie gehad en is verhinder om ' $n$ effektiewe teenbombardement te lewer. ${ }^{45}$

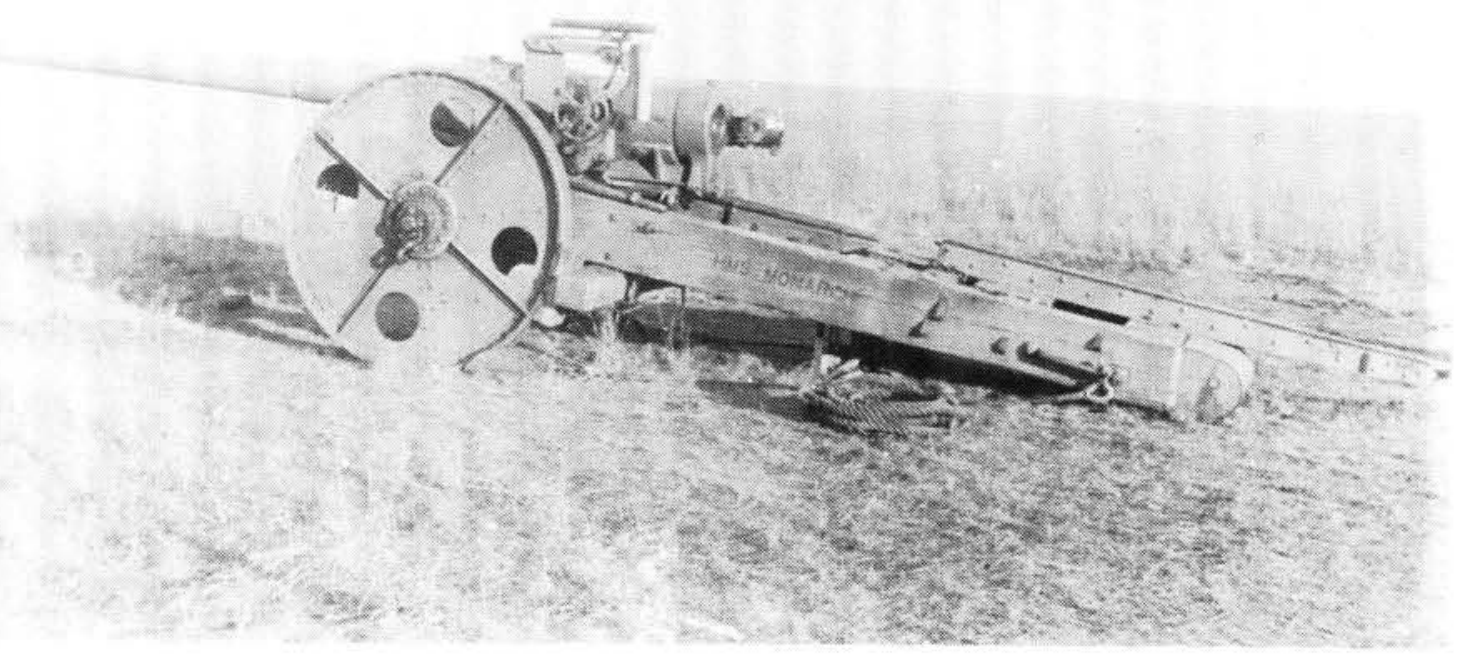

'n 4.7" Vlootkanon. Hierdie kanon het van Swartkoppies op Pienaarspoort gevuur

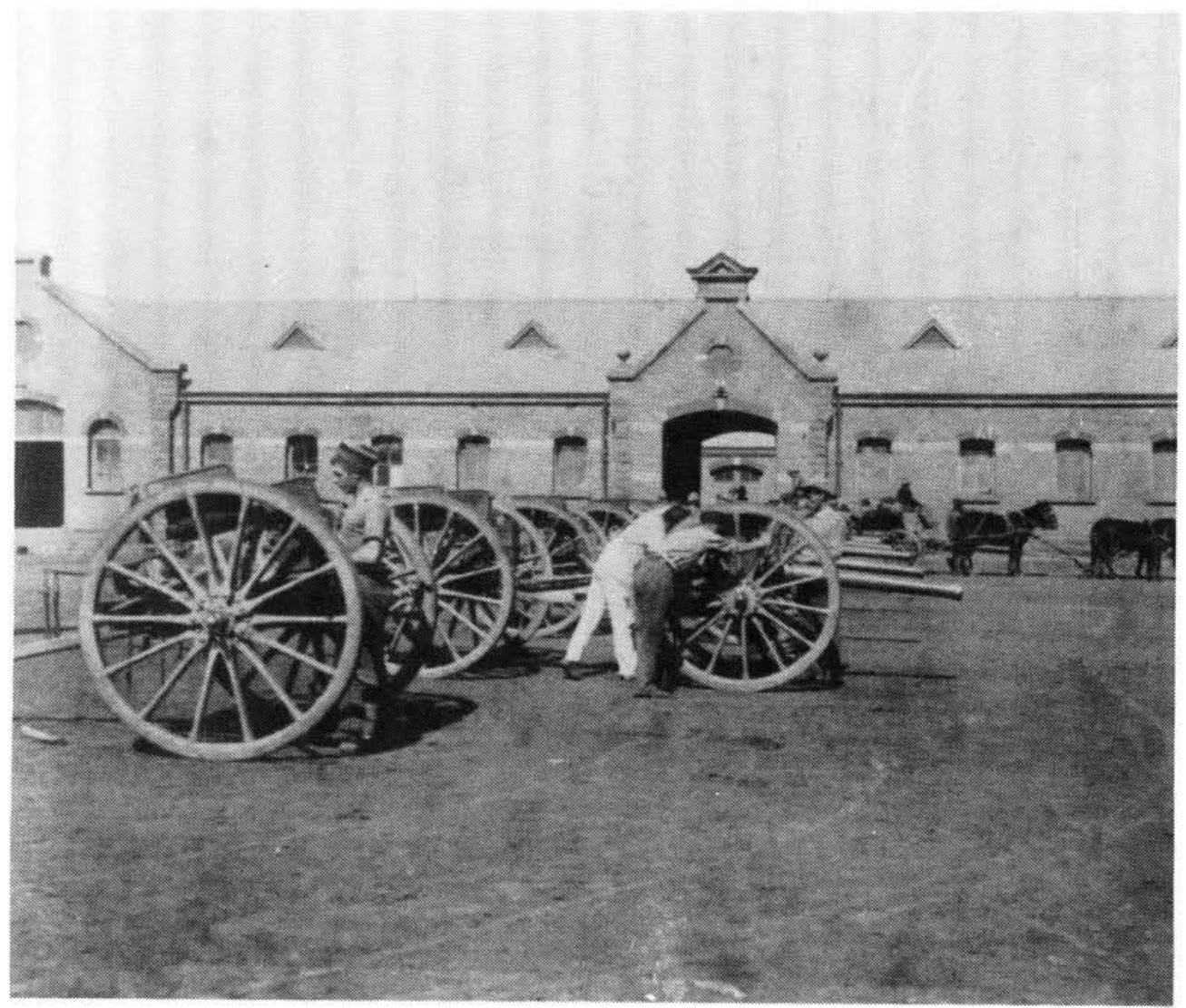

Kanonne van die 75e Royal Field Artillery in die Barakke te Pretoria 
Namate De La Rey se burgers besef het dat hul vyand in die moeilikheid verkeer, het hulle meer aggressief geword en French met groter durf begin aanval. Teen die middag was De La Rey oortuig dat die tyd aangebreek het om 'n kragtige teenaanval teen French te loods. Hy het ' $n$ boodskap aan Louis Botha gestuur om versterkings te vra wat hom in staat sou stel om French te oorweldig, op Roberts se swak sentrum toe te slaan en lan Hamilton dan in die rug te pak. Botha het die versoek teen 16 hoo ontvang en versterkings uit die sentrum soontoe beveel, maar voordat hulle kon wegkom, het 'n boodskap van genl Fourie hom bereik waarin hy meegedeel is dat Renosterfonteinkop verower is en dat die vyand in besit was van die hele Diamond Hill-plato. Die Kommandant-generaal het daarop die versterkings beveel om terug te keer.

De La Rey het nou op die punt gestaan om tot die teenaanval oor te gaan en 'n beslissende slag te slaan. Die verloop van die geveg op die suidelike flank het egter sy planne in die wiele gery. Net toe hy gereed was om met sy kommando's - wat op daardie tydstip hoogstens
1200 man getel het - op French toe te sak, het Louis Botha se boodskap hom bereik dat die vyand suid van Donkerhoek deurgebreek het en hom in die rug bedreig. Hy moes gevolglik sy kommando's se terugtog beveel. ${ }^{47}$

Soos Roberts en Ian Hamilton was French salig onbewus daarvan dat die Boerekommando's voor hom besig was om hul stellings te ontruim en het hy, in afwagting van 'n aanval teen dagbreek, opdrag gegee dat die troepe, soos die vorige aand, in die posisies wat hulle beset het, moes oornag. ${ }^{48}$

\section{Slotbeskouing}

As die Britse generaals teen 16h30, toe hulle besluit het om nie met die aanval te volhard nie, besef het hoe naby hulle aan 'n deurbraak was, sou hulle seker alles in die stryd gewerp en die risiko van verliese getrotseer het om ' $n$ beslissing af te dwing. ${ }^{49}$

Die hele dag het sy burgers, volgens Botha, hard en swaar geveg, sodat hy pres Kruger verseker het dat "ik onze menschen nog nooit

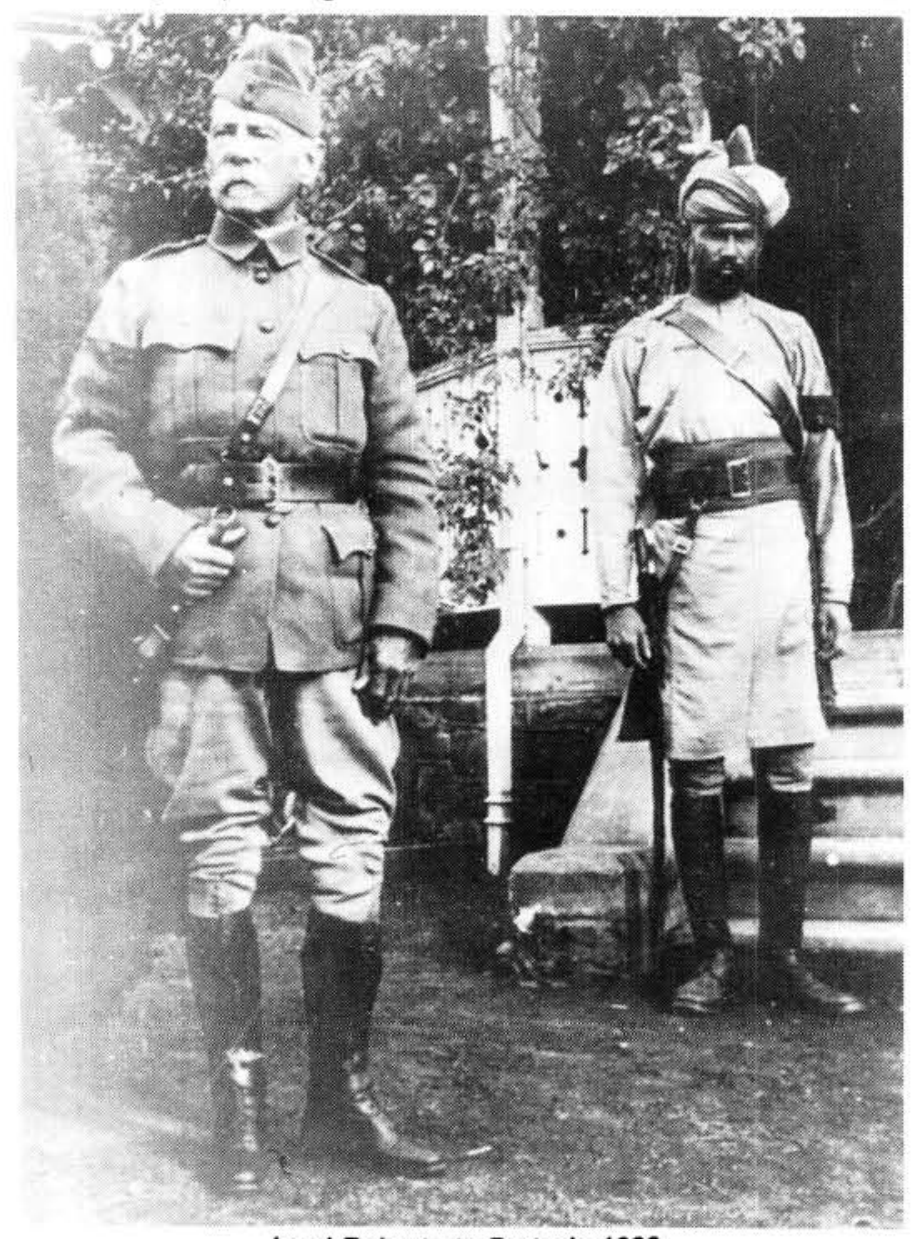

Lord Roberts te Pretoria 1900 
mooier heb zien staan."50 Op die noordelike flank was genl De La Rey gereed om tot die aanval oor te gaan en French te oorrompel. Dit sou hom in die rug van Roberts se hoogmag plaas, die Britte se terugtoglinie bedreig en Roberts dwing om lan Hamilton se troepe op die suidelike flank onmiddellik terug te trek. ${ }^{41}$

Vir lord Roberts, en die twee generaals Hamilton, het die situasie op die suidelike flank rede tot tevredenheid gebied. Hoewel hulle nie daarin kon slaag om deur die Boerelinie te breek nie, het hulle tog daarin geslaag om die sterktepunte in dié deel van die linie te verower, vanwaar hulle die laagliggende stellings kon beheer. Hulle was daarvan oortuig dat 'n beslissende deurbraak die volgende dag gemaak sou word en was daarmee tevrede. Volgens Smuts sou niks Hamilton se mag kon verhoed het om daardie selfde nag nog Elandsfonteinstasie in die rug van die Boeremag te beset nie. In plaas daarvan om dit te doen het hulle toegelaat dat Botha se mag ongesteurd onder hulle neuse uitglip en in goeie orde terugval. ${ }^{52}$

Roberts se verklaarde doel met die operasie was om die Boere verder van Pretoria weg te dryf en daarin het hy geslaag. Sy krygsplan was egter daarop gemik om met 'n vinnige beweging agter Botha se rug in te sny, hom die terugtog te belet en sodoende die Transvaalse hoofmag te vernietig. Daarin het hy nie geslaag nie. Die operasie wat in 'n lotsbestemmende oorwinning vir die Britse mag moes eindig, wat dus die einde van die oorlog sou beteken, het bloot 'n verdrywingsaksie geword, wat die Boere as 'n morele oorwinning vir hulself beskou het en waaruit hulle feitlik ongeskonde getree het om as 'n vegwaardige mag die stryd voort te sit. ${ }^{53}$ Vir die Boere was die slag 'n morele oorwinning al moes hulle die linie uiteindelik prysgee. Die vasberadenheid waarmee 'n groot deel van die burgers geveg het, het getoon dat daar nog baie vegkrag en moed in die Boeremag opgesluit was en dat die oorlog nie verby was, soos Roberts na die inname van die hoofstad gemeen het nie. In 'n sekere sin kan 'n mens sê dat die slag 'n keerpunt in die oorlog gevorm het. Vir die Boereleiers het dit duidelik geword dat die konvensionele manier van oorlogvoering, waardeur hulle met groot magte voor die Britte stelling ingeneem het om telkens maar weer teruggedryf te word, uitgedien was. In die OranjeVrystaat het De Wet reeds getoon watter sukses behaal kon word deur met kleiner kommando's, wat vinnig kon beweeg, in die rug van die vyand toe te slaan. Ook in die Transvaal sou die stryd ná Donkerhoek dus begin verander en sou dit uiteindelik ook in 'n guerilla-kryg ontwikkel.

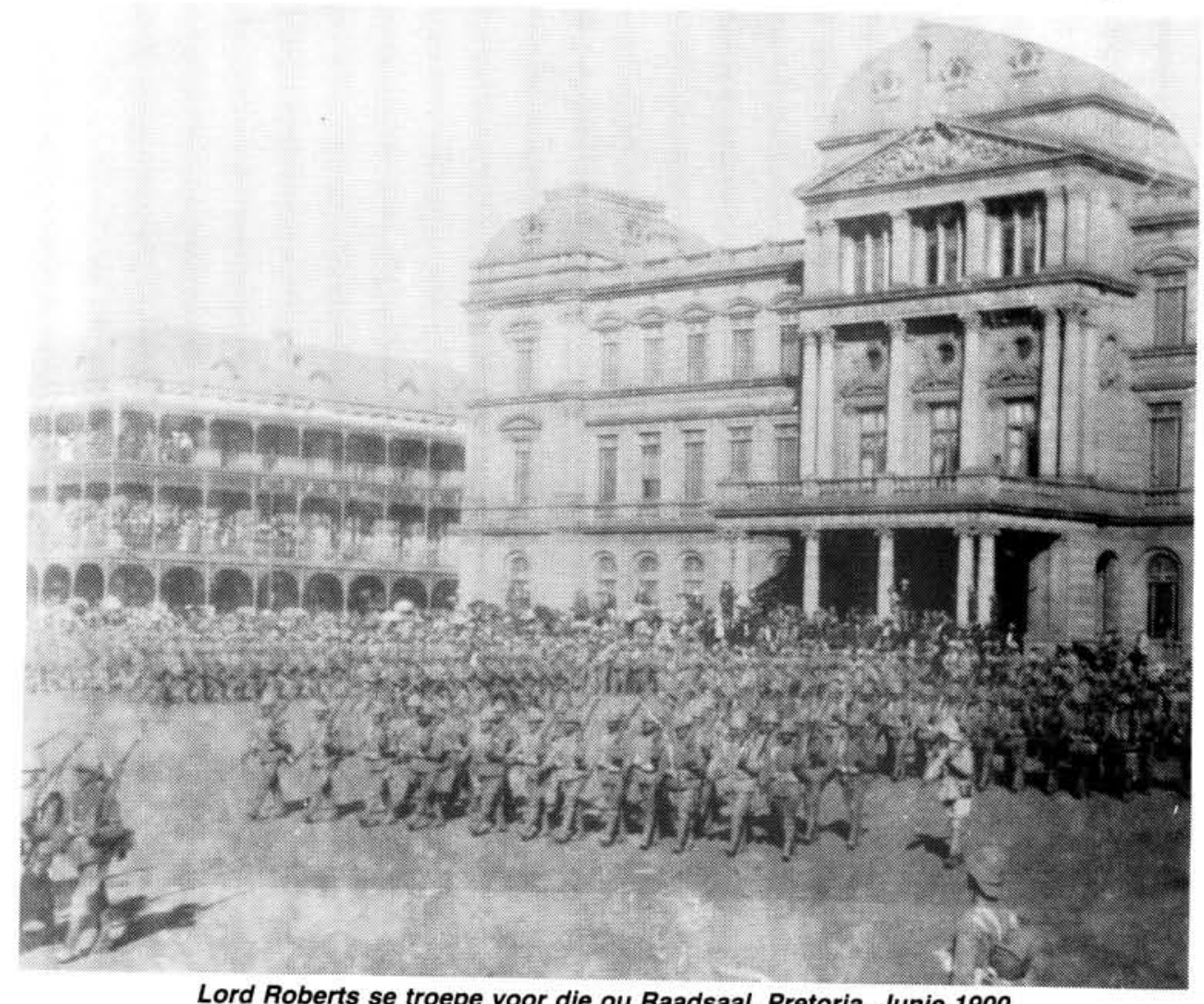

Lord Roberts se troepe voor die ou Raadsaal, Pretoria, Junie 1900 


\section{* H.F. Nel (Kdoor-aftr) MA, Educ. HOD.}

\section{Bibliografie}

1. C.S. Goldman, with General French and the cavalry in South Africa, p. 276.

2. Official History III, p. 209.

3. Ibid, pp. 209-210.

4. A.E. Breytenbach, Die Slag by Donkerhoek, 11-12 Junie 1900, pp. $87-88$.

5. Soos aangehaal uit A.E. Breytenbach, "Die Slag by Donkerhoek $11+12$ Junie 1900", p. 88

6. Ibid, pp. $88-89$.

7. Ibid, p. 89 .

8. Official History, III, pp. 210-211; W.K. Hancock en J. van der Poel, Selections from the Smuts Papers, p. 558.

9. Soos aangehaal uit A.E. Breytenbach, Die Slag by Donkerhoek 11-12 Junie 1900" p. 91.

10. Ibid, p. 92.

11. Ibid, pp. 93-94.

12. Lord Roberts Papers, Vol. 7, p. 20 Bruce Hamilton se verslag dd. 17 Junie 1900.

13. Official History III, p. 213.

14. Official History III, p. 213; Lord Roberts Papers, Vol 7, p. 46, Broadwood se verslag dd. 17 Junie 1900

15. A.E. Breytenbach, Die Slag by Donkerhoek 11-12 Junie 1900", p. 100.

16. Ibid, p. 100.

17. Ibid, p. 101

18. Ibid, pp. 102-103.

19. Times History IV, pp. 283-284, W.S. Churchill, lan Hamilton's March, pp. 388-389.

20. Official History III, p. 215, Times History IV, pp. 281-282.

21. Soos aangehaal uit A.E. Breytenbach, Die Slag by Donkerhoek 11-12 Junie 1900", p. 91.

22. Ibid, p. 108.
23. Lord Roberts Papers, Vol 34, pp. 133-134, Ian Hamilton aan Roberts 11 Junie 1900; W.S. Churchill, Ian Hamilton's March, p. 390.

24. Lord Roberts Papers, Vol 7, p 22 Bruce Hamilton se verslag dd. 17 Junie 1900.

25. Soos aangehaal uit A.E. Breytenbach "Die Slag by Donkerhoek 11-12 Junie 1900", pp. 109-110.

26. Ibid, p. 110

27. Ibid, p. 111

28. Ibid, p. 113

29. Ibid, p. 114-115.

30. Ibid, p. 116.

31. Ibid, p. 119

32. Leyds $753(1)$, p. 143, №. 33 Botha aan Grobler, 12 Jnie 1900

33. Soos aangehaal uit A.E. Breytenbach, "Die Slag by Donkerhoek 11-12 Junie 1900", pp. 120-121.

34. Ibid, pp. 121-124.

35. Ibid, p. 125.

36. Ibid, p. 126.

37. Ibid, p. $127-128$.

38. Ibid, pp. 128-129

39. Ibid, p. 130

40. Official History III, p. 221; Times History IV, p. 291

41. Official History III, p. 221

42. Soos aangehaal uit A.E. Breytenbach, "Die Slag by Donkerhoek 11-12 Junie $1900 "$, p. 132

43. Ibid, pp. 132-133.

44. Ibid, p. 133

45. Ibid, p. 134

46. Ibid, pp. $134-135$

47. Ibid, p. 136

48. Ibid, p. 137

49. Ibid, p. 137

50. Ibid, p. 137

51. Ibid, p. 139

52. Ibid, p. 155 